Ann. Biol. anim. Bioch. Biophys., I976, $16(6), 773-782$.

\title{
EFFECT OF TEMPERATURE ON SURVIVAL DURING THE FIRST MONTH OF LIFE IN THE FIELD VOLE, MICROTUS ARVALIS, RAISED UNDER DIFFERENT CONDITIONS OF DAYLIGHT RATIO AND FEEDING
}

\author{
Lise MARTINET and Marie-José DAKETSE* \\ with the technical assistance of Viviane GARNIER \\ Station centrale de Physiologie animale, I. N. R. A., \\ 78350 Jouy en Josas, France \\ - Laboratoire d'Histologie et Embryologie, \\ Centre hospitalier de Bicêtre, \\ 78, avenue du Général Leclerc, \\ 94270 Le Kremlin Bicêtre, France
}

\section{SUMMARY}

The temperature at which field-vole pups are raised plays a principal role in their survival during the first month of life. Mortality rise as the temperature drops, is explained by inefficient thermoregulation at weaning.

The quality of the alfalfa eaten also affects survival, i.e. alfalfa harvested at an early stage of vegetation in the spring enhances the chances of survival of the pups more than alfafa harvested at a later stage of vegetation in the fall.

Daylight ratio does not affect survival from birth to 30 days.

Low temperature and fall alfalfa, the two factors unfavorable to survival, may partially explain the mortality rates observed in nature during the first months of life.

At the present time it is impossible to directly measure mortality rate during the first month of life in natural field-vole populations because these animals cannot be captured. Ecologists must thus use indirect methods (SpITz, I974). However, the juvenile population within herbivorous small rodent populations is very high. KREBS et al. (rg6g) estimate that only $20 \mathrm{p}$. roo of young Microtus pennsylranicus 
or Microtus ochrogaster survive between birth and one month. In Microtus arvalis mortality rates range between 40 and $90 \mathrm{p}$. Ioo during the year (MARTINET and SpITZ, I97I).

The effect of some environmental factors on juvenile mortality can be measured on animals in captivity. A previous study (MARTINET and MEUNIER, I969) showed the importance of the feeding value of the vegetation eaten in relation to survival rate; numerous other factors probably play a role, and that is why we have studied the effect of temperature associated to various stock-raising conditions.

\section{MATERIAL AND METHODS}

\section{Animals}

The female is given wood shavings and hay to make her nest. From the day of birth the cages containing the mothers and their pups are separated into different experimental groups. At I 4 days the female is taken from the cage. The pups are thus weaned but may stay in the nest up to one month, at which time they are isolated in individual cages.

\section{Series 1.}

Experimental groups

Twelve groups of animals were constituted according to a $3 \times 2 \times 2$ experimental design; they were raised under the following environmental conditions :

- three temperatures: $5^{\circ} \mathrm{C}, 22^{\circ} \mathrm{C}$ or $33^{\circ} \mathrm{C}$.

During the experiment temperatures varied in the first case between $3^{\circ} \mathrm{C}$ and $9^{\circ} \mathrm{C}$, in the second case between $20^{\circ} \mathrm{C}$ and $25^{\circ} \mathrm{C}$ and in the third case between $28^{\circ} \mathrm{C}$ and $35^{\circ} \mathrm{C}$.

- two diets : spring or summer alfalfa.

The alfalfa was cut at an early stage of growth $(30 \mathrm{~cm})$, either during the first vegetative cycle in April (spring alfalfa) or during the second vegetative cycle in June (summer alfalfa). It was ground and dried, then wetted again when distributed daily ad libitum. No other water was given.

- two daylight ratios : $15 \mathrm{~h}$ or Io $\mathrm{h}$ of light per $24 \mathrm{~h}$. Light level in the cages ranged between 200 and 300 lux.

Ambient humidity recorded throughout the experiment varied between 40 and $85 \mathrm{p}$. Ioo at $5^{\circ} \mathrm{C}$, between 30 and $75 \mathrm{p}$. Ioo at $22^{\circ} \mathrm{C}$, and between $4^{\circ}$ and $45 \mathrm{p}$. 10o at $33^{\circ} \mathrm{C}$.

\section{Series 2 .}

Eight groups of animals were constituted according to a $2 \times 2 \times 2$ experimental design and raised under the following environmental conditions :

- two temperatures : $5^{\circ} \mathrm{C}$ or $22^{\circ} \mathrm{C}$. Fluctuations are the same as in series $\mathrm{r}$.

- two diets: spring or fall alfalfa. The alfalfa was cut, either at an early vegetative stage of growth $(30 \mathrm{~cm})$ during the first vegetation cycle in April (spring alfalfa) or at a later stage of growth (60 $\mathrm{cm}$ or preflowering) during the fourth vegetation cycle in October (fall alfalfa). In this series alfalfa was deep-frozen ${ }_{5} 5$ minutes after harvesting and stored at $-18^{\circ} \mathrm{C}$ until utilization. It was given in the frozen state daily ad libitum.

- two daylight ratios : $15 \mathrm{~h}$ or $10 \mathrm{~h}$ of light per $24 \mathrm{~h}$.

\section{Series 3.}

Eight groups identical to those of series 2 were constituted, but the pups were separated from the mother one week later, i.e. at $2 \mathrm{I}$ days instead of at $\mathrm{I}_{4}$ days.

\section{Observations}

The pups in each series were counted at birth and again at $7,14,21$ and 30 days ; every day any dead animals were removed from the nests. Litters were weighed at $7, I_{4}$ and 21 days. In some cases, pups were weighed individually at $\mathrm{I}_{4}$ days.

Survival rates were compared using the $\chi^{2}$ test. 


\section{RESULTS}

The role of ambient temperature in the survival of the young depends on many factors which are analyzed successively.

\section{I. - Effect of age of animals}

During the first week mortality of the pups living at $5^{\circ} \mathrm{C}$ or at $22^{\circ} \mathrm{C}$ was the same; it varied between 3 and $9 \mathrm{p}$. Ioo in the first series (table I), and between 7 and $29 \mathrm{p}$. Ioo in the second series (table 2). In the first series mortality was the highest at $33^{\circ} \mathrm{C}$, i.e. at 7 days 8 to $22 \mathrm{p}$. Ioo of the pups were dead. The difference between the $33^{\circ} \mathrm{C}$ groups on one hand and the $5^{\circ} \mathrm{C}$ and $22^{\circ} \mathrm{C}$ groups on the other, was significant in 3 cases out of 4 (table $\mathrm{I}$ ).

During the second week mortality increased at $5^{\circ} \mathrm{C}$. However, results varied from one group to another since there is I to $22 \mathrm{p}$. I00 mortality in series $I$, and 20 to 34 p. roo mortality in series 2 .

TABLE I

Juvenile mortality rate during the first four weeks of life

Results are expressed in percentage of young dead at a given age

as compared to those dead at the preceding age (series $\mathbf{I}$ )

\begin{tabular}{|c|c|c|c|c|c|c|c|c|}
\hline \multirow[b]{2}{*}{$\begin{array}{c}\text { Daylight } \\
\text { ratio }\end{array}$} & \multirow[b]{2}{*}{ Diet } & \multirow[b]{2}{*}{$\begin{array}{l}\text { Tempe- } \\
\text { rature }\end{array}$} & \multirow{2}{*}{$\begin{array}{c}\text { Number } \\
\text { born }\end{array}$} & \multirow[b]{2}{*}{$\begin{array}{c}\begin{array}{c}\text { Litter } \\
\text { size }\end{array} \\
-\end{array}$} & \multicolumn{4}{|c|}{ Mortality rate (in $\%$ ) from } \\
\hline & & & & & $\begin{array}{l}0 \text { to } 7 \\
\text { days }\end{array}$ & $\begin{array}{c}7 \text { to } 14 \\
\text { days }\end{array}$ & $\begin{array}{c}14 \text { to } 21 \\
\text { days }\end{array}$ & $\begin{array}{c}21 \text { to } 30 \\
\text { days }\end{array}$ \\
\hline \multirow{2}{*}{$15 \mathrm{~L}: 9 \mathrm{D}$} & $\begin{array}{l}\text { Spring } \\
\text { alfalfa }\end{array}$ & $\begin{array}{r}5^{\circ} \mathrm{C} \\
22^{\circ} \mathrm{C} \\
33^{\circ} \mathrm{C}\end{array}$ & $\begin{array}{l}120 \\
155 \\
156\end{array}$ & $\begin{array}{l}4.8 \\
4.4 \\
4.1\end{array}$ & $\begin{array}{l}4 \\
4 \\
8\end{array}$ & $\begin{array}{c}14^{*} \\
0 \\
4\end{array}$ & $\begin{array}{l}77^{* *} \\
23^{*} \\
2\end{array}$ & $\begin{array}{l}0 \\
9 \\
0\end{array}$ \\
\hline & $\begin{array}{c}\text { Summer } \\
\text { alfalfa }\end{array}$ & $\begin{array}{r}5^{\circ} \mathrm{C} \\
22^{\circ} \mathrm{C} \\
33^{\circ} \mathrm{C}\end{array}$ & $\begin{array}{l}166 \\
115 \\
135\end{array}$ & $\begin{array}{l}5.2 \\
4.3 \\
4.8\end{array}$ & $\begin{array}{c}3 \\
4 \\
11^{*}\end{array}$ & $\begin{array}{c}22^{* *} \\
1 \\
1\end{array}$ & $\begin{array}{c}76^{* *} \\
37^{* *} \\
7\end{array}$ & $\begin{array}{c}6 \\
23^{*} \\
6\end{array}$ \\
\hline \multirow{2}{*}{$10 \mathrm{~L}: 14 \mathrm{D}$} & $\begin{array}{l}\text { Spring } \\
\text { alfalfa }\end{array}$ & $\begin{array}{r}5^{\circ} \mathrm{C} \\
22^{\circ} \mathrm{C} \\
33^{\circ} \mathrm{C}\end{array}$ & $\begin{array}{l}164 \\
118 \\
133\end{array}$ & $\begin{array}{l}4.1 \\
3.9 \\
4.8\end{array}$ & $\begin{array}{c}9 \\
8 \\
22^{* *}\end{array}$ & $\begin{array}{l}3 \\
1 \\
3\end{array}$ & $\begin{array}{c}12\left({ }^{1}\right) \\
5 \\
0\end{array}$ & $\begin{array}{l}26^{*}\left({ }^{1}\right) \\
6 \\
14\end{array}$ \\
\hline & $\begin{array}{c}\text { Summer } \\
\text { alfalfa }\end{array}$ & $\begin{array}{r}5^{\circ} \mathrm{C} \\
22^{\circ} \mathrm{C} \\
33^{\circ} \mathrm{C}\end{array}$ & $\begin{array}{r}117 \\
91 \\
80\end{array}$ & $\begin{array}{l}4.6 \\
4.3 \\
4.4\end{array}$ & $\begin{array}{c}4 \\
4 \\
20^{* *}\end{array}$ & $\begin{array}{l}1 \\
3 \\
0\end{array}$ & $\begin{array}{l}73^{* *} \\
13 \\
24\end{array}$ & $\begin{array}{l}19^{* * *} \\
0 \\
0\end{array}$ \\
\hline
\end{tabular}

* $\mathrm{P}<0.05]$ Comparisons are made within the same group between $5^{\circ} \mathrm{C}$ and $21^{\circ} \mathrm{C}$

** $\mathrm{P}<0.01$ and between $22^{\circ} \mathrm{C}$ and $33^{\circ} \mathrm{C}$.

$\left.{ }^{(}\right)$Females of this group were given cellulose handkerchiefs for nest construction besides shavings and hay. 
At $22^{\circ} \mathrm{C}$ and $33^{\circ} \mathrm{C}$ mortality is very low between 7 and 14 days; at $22^{\circ} \mathrm{C}$ the high disappearance rates of the two groups fed fall alfalfa (table 2 ) are due to the feeding value of the alfalfa which is analyzed further on.

TABLE 2

Mortality rate of young during the first four weeks of life

Results are expressed in percentage of young dead at a given age as compared to those dead at the preceding age (series 2)

\begin{tabular}{|c|c|c|c|c|c|c|c|c|}
\hline \multirow{2}{*}{$\begin{array}{l}\text { Daylight } \\
\text { ratio }\end{array}$} & \multirow[b]{2}{*}{ Diet } & \multirow{2}{*}{$\begin{array}{l}\text { Tempe- } \\
\text { rature }\end{array}$} & \multirow{2}{*}{$\begin{array}{c}\text { Number } \\
\text { born }\end{array}$} & \multirow{2}{*}{$\begin{array}{l}\text { Litter } \\
\text { size }\end{array}$} & \multicolumn{4}{|c|}{ Mortality rate (in $\%$ ) from } \\
\hline & & & & & $\begin{array}{l}0 \text { to } 7 \\
\text { days }\end{array}$ & $\begin{array}{l}7 \text { to } 14 \\
\text { days }\end{array}$ & $\begin{array}{l}14 \text { to } 21 \\
\text { days }\end{array}$ & $\begin{array}{c}21 \text { to } 30 \\
\text { days }\end{array}$ \\
\hline \multirow{2}{*}{$15 \mathrm{~L}: 9 \mathrm{D}$} & $\begin{array}{l}\text { Spring } \\
\text { alfalfa }\end{array}$ & $\begin{array}{r}5^{\circ} \mathrm{C} \\
22^{\circ} \mathrm{C}\end{array}$ & $\begin{array}{r}109 \\
86\end{array}$ & $\begin{array}{l}5.1 \\
5.3\end{array}$ & $\begin{array}{r}17 \\
7\end{array}$ & $\begin{array}{c}34 * * \\
3\end{array}$ & $\begin{array}{l}51^{* *} \\
12\end{array}$ & $\begin{array}{r}0 \\
11\end{array}$ \\
\hline & $\begin{array}{c}\text { Fall } \\
\text { alfalfa }\end{array}$ & $\begin{array}{r}5^{\circ} \mathrm{C} \\
22^{\circ} \mathrm{C}\end{array}$ & $\begin{array}{l}116 \\
142\end{array}$ & $\begin{array}{l}5.2 \\
4.7\end{array}$ & $\begin{array}{l}29 \\
27\end{array}$ & $\begin{array}{l}28 \\
29\end{array}$ & $\begin{array}{l}63 \\
62\end{array}$ & $\begin{array}{c}26^{*} \\
0\end{array}$ \\
\hline \multirow{2}{*}{$10 \mathrm{~L}: 14 \mathrm{D}$} & $\begin{array}{l}\text { Spring } \\
\text { alfalfa }\end{array}$ & $\begin{array}{r}5^{\circ} \mathrm{C} \\
22^{\circ} \mathrm{C}\end{array}$ & $\begin{array}{l}83 \\
52\end{array}$ & $\begin{array}{l}4.9 \\
5.3\end{array}$ & $\begin{array}{r}16 \\
9\end{array}$ & $\begin{array}{c}32^{* *} \\
3\end{array}$ & $\begin{array}{l}67 \\
43\end{array}$ & $\begin{array}{r}11 \\
4\end{array}$ \\
\hline & $\begin{array}{c}\text { Fall } \\
\text { alfalfa }\end{array}$ & $\begin{array}{r}5^{\circ} \mathrm{C} \\
22^{\circ} \mathrm{C}\end{array}$ & $\begin{array}{l}103 \\
143\end{array}$ & $\begin{array}{l}4.8 \\
4.9\end{array}$ & $\begin{array}{l}26 \\
29\end{array}$ & $\begin{array}{l}20^{*} \\
40\end{array}$ & $\begin{array}{l}65^{*} \\
33\end{array}$ & $\begin{array}{l}62^{*} \\
48\end{array}$ \\
\hline $\begin{array}{r}* \mathrm{P}< \\
* \mathrm{P}<\end{array}$ & .05 & arisons & nade & a the & roup & en tem & ures. & \\
\hline
\end{tabular}

From weaning on (after $\mathrm{I} 4$ days) there is considerable mortality in young raised at $5^{\circ} \mathrm{C}$. Disappearance rates between $\mathrm{I} 4$ and $2 \mathrm{I}$ days vary between $5 \mathrm{I}$ and 77 p. roo ; most of the animals die in the three days following weaning.

Mortality at $22^{\circ} \mathrm{C}$, although lower than at $5^{\circ} \mathrm{C}$, ranges between 5 and $73 \mathrm{p}$. Ioo in the first series, between $\mathrm{I} 2$ and $62 \mathrm{p}$. Ioo in the second one. At $33^{\circ} \mathrm{C}$ mortality rate does not exceed $24 \mathrm{p}$. Ioo between $\mathrm{I} 4$ and $2 \mathrm{I}$ days.

After 21 days mortality decreases in all groups except two in which animals were fed fall alfalfa.

$$
\text { 2. - Effect of diet }
$$

Survival rates during the first month are the same in the groups fed spring or summer alfalfa. However, a lower survival rate is observed $(P<0.05)$ in one case when summer alfalfa is given (table 3 ).

Fall alfalfa is very unfavorable to survival of the pups. The difference between spring and fall alfalfa is significant $(P<0.0 I)$ in the two $22^{\circ} \mathrm{C}$ groups. This unfavorable effect of fall alfalfa already appears in the first week of life (table 2 ).

\section{3. - Influence of daylight ratio}

No effect of the daylight ratio on the survival of young was observed. 
TABLE 3

Mortality rate of young between 14 and 21 days in relation to weight at 14 days

(Weight of young is obtained by dividing litter weight by the number of young alive)

\begin{tabular}{|c|c|c|c|c|c|}
\hline $\begin{array}{l}\text { Daylight } \\
\text { ratio }\end{array}$ & Diet & Temperature & $\begin{array}{c}\text { Number of } \\
\text { litters }\end{array}$ & $\begin{array}{c}\text { Mean weight } \\
g \pm \mathrm{S} . \mathrm{E} .\end{array}$ & $\begin{array}{l}\text { Mortality } \\
\text { rate in p. } 100\end{array}$ \\
\hline \multirow{2}{*}{$15 \mathrm{~L}: 9 \mathrm{D}$} & $\begin{array}{l}\text { Spring } \\
\text { alfalfa }\end{array}$ & $\begin{array}{r}5^{\circ} \mathrm{C} \\
22^{\circ} \mathrm{C} \\
33^{\circ} \mathrm{C}\end{array}$ & $\begin{array}{l}25 \\
35 \\
38\end{array}$ & $\begin{array}{l}8.6 \pm 0.7^{*} \\
7.2 \pm 0.3 \\
6.9 \pm 0.2\end{array}$ & $\begin{array}{c}77^{*} \\
23 \\
2\end{array}$ \\
\hline & $\begin{array}{l}\text { Summer } \\
\text { alfalfa }\end{array}$ & $\begin{array}{r}5^{\circ} \mathrm{C} \\
22^{\circ} \mathrm{C} \\
33^{\circ} \mathrm{C}\end{array}$ & $\begin{array}{l}32 \\
23 \\
23\end{array}$ & $\begin{array}{l}7.4 \pm 0.5^{*} \\
6.2 \pm 0.2 \\
6.2 \pm 0.2\end{array}$ & $\begin{array}{c}76^{*} \\
37 \\
7\end{array}$ \\
\hline \multirow{2}{*}{$10 \mathrm{~L}: 14 \mathrm{D}$} & $\begin{array}{l}\text { Spring } \\
\text { alfalfa }\end{array}$ & $\begin{array}{r}5^{\circ} \mathrm{C} \\
22^{\circ} \mathrm{C} \\
33^{\circ} \mathrm{C}\end{array}$ & $\begin{array}{l}38 \\
30 \\
26\end{array}$ & $\begin{array}{l}9.5 \pm 0.4^{*} \\
8.9 \pm 0.3 \\
7.4 \pm 0.3\end{array}$ & $\begin{array}{l}12(1) \\
5 \\
0\end{array}$ \\
\hline & $\begin{array}{l}\text { Summer } \\
\text { alfalfa }\end{array}$ & $\begin{array}{r}5^{\circ} \mathrm{C} \\
22^{\circ} \mathrm{C} \\
33^{\circ} \mathrm{C}\end{array}$ & $\begin{array}{l}24 \\
21 \\
18\end{array}$ & $\begin{array}{l}7.7 \pm 0.3 \\
8.2 \pm 0.3 \\
7.3 \pm 0.3\end{array}$ & $\begin{array}{c}73^{*} \\
0 \\
0\end{array}$ \\
\hline
\end{tabular}
hay.

(1) Females of this group were given cellulose handkerchiefs for nest construction besides shavings and

$* \mathrm{P}<0.01$ Comparisons are made within the same group between $5^{\circ} \mathrm{C}, 21^{\circ} \mathrm{C}$ and $33^{\circ} \mathrm{C}$.

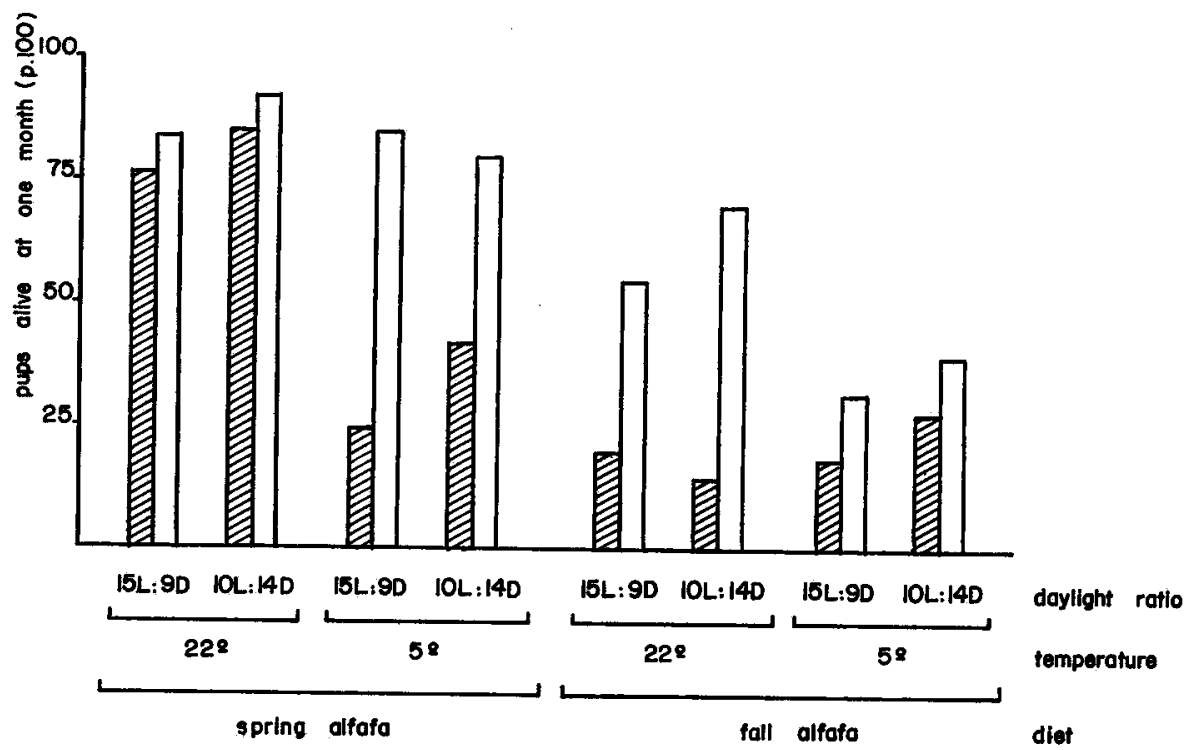

FIG. I. - Effect of age at weaning on survival of young.

E Weaning at 14 days

$\sqcap$ Weaning at $2 I$ days 


\section{4. - Effect of age of pups at weaning}

Weaning at $2 \mathrm{I}$ days instead of at I4 days considerably improved future survival rate of the pups. Increase of survival rate is especially clear in animals raised at $22^{\circ} \mathrm{C}$ and fed fall alfalfa or raised at $5^{\circ} \mathrm{C}$ and fed spring alfalfa. In groups where both factors unfavorable to survival $\left(5^{\circ} \mathrm{C}\right.$ and fall alfalfa) are associated, mortality between $I_{4}$ and $2 \mathrm{I}$ days remains high in spite of the maternal presence (text fig. I).

\section{5. - Effect of weight of pups at weaning}

The weight of pups at weaning determines their future survival. The minimum weight necessary for survival increases when the temperature at which animals are raised decreases. This is shown by the following facts :

- survival rates after weaning are much better at $33^{\circ} \mathrm{C}$ than at $22^{\circ} \mathrm{C}$ or $5^{\circ} \mathrm{C}$, while pups raised at $33^{\circ} \mathrm{C}$ are the smallest (table 3 ).

- at $22^{\circ} \mathrm{C}$ pups weighing at least 5 grams have a $5^{\circ}$ to $80 \mathrm{p}$. Ioo chance of surviving; if raised at $5^{\circ} \mathrm{C}$ pups must weight more than 7.5 grams to have the same chance of surviving. At $33^{\circ} \mathrm{C}$, where survival rates after weaning are always higher than $75 \mathrm{p}$. Ioo, there seems to be no relation between body weight and survival (table 4).

\section{TABLE 4}

Survival rate of young during the week following weaning in relation to weaning time

(Young were weighed individually)

\begin{tabular}{|c|c|c|c|}
\hline \multirow{2}{*}{ Diet } & \multirow{2}{*}{$\begin{array}{l}\text { Weight at } 14 \text { days } \\
\text { in grams }\end{array}$} & \multicolumn{2}{|c|}{$\begin{array}{c}\text { Survival rate between } \\
14 \text { and } 21 \text { days }\end{array}$} \\
\hline & & $2 \pm 20^{\circ} \mathrm{C}$ & $5^{\circ} \mathrm{C}$ \\
\hline $\begin{array}{l}\text { Spring } \\
\text { alfalfa }\end{array}$ & $\begin{array}{l}\leqslant 5 \\
5.1 \text { to } 7.5 \\
>7.5\end{array}$ & $\begin{array}{l}38 \\
80 \\
98\end{array}$ & $\begin{array}{r}10 \\
6 \\
68\end{array}$ \\
\hline $\begin{array}{l}\text { Fall } \\
\text { alfalfa }\end{array}$ & $\begin{array}{c}\leqslant 5 \\
5.1 \text { to } 7.5 \\
>7.5\end{array}$ & $\begin{array}{l}15 \\
50 \\
91\end{array}$ & $\begin{array}{r}0 \\
0 \\
52\end{array}$ \\
\hline
\end{tabular}

\section{6. - Effect of litter weight at weaning}

Whole litters dead between $\mathrm{I} 4$ and $2 \mathrm{I}$ days at $5^{\circ} \mathrm{C}$ and $22^{\circ} \mathrm{C}$ weigh on an average 6 grams less at $\mathrm{I}_{4}$ days than those totally surviving. The difference is not significant because of the wide variability in litter weight ( 6 to 54 grams). At $33^{\circ} \mathrm{C}$ very few litters disappear entirely after weaning (table 5).

The relation litter weight-future survival in terms of ambient temperature is much less clear than that of individual weight-survival. 
TABLE 5

Effect of litter weight at weaning cn future survival of the young

(6r) Number of litters

\begin{tabular}{|c|c|c|}
\hline \multirow{2}{*}{ Temperature } & \multicolumn{2}{|c|}{ Litter weight at 14 days } \\
\hline & Alive at 21 days & Dead at 21 days \\
\hline 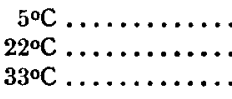 & $\begin{array}{l}32.4 \pm 3.1(61) \\
32.0 \pm 3.3(108) \\
24.9 \pm 4.1(131)\end{array}$ & $\begin{array}{l}26.1 \pm 2.1(69) \\
26.6 \pm 1.8(22) \\
28.9 \pm 4.3(15)\end{array}$ \\
\hline
\end{tabular}

The number of young born per litter range from $I$ to 6 . Litter size does not seem to affect survival from birth to weaning or from weaning to one month. However, postweaning survival rate is higher in larger litters, probably because their weight is higher than that of the smaller litters.

\section{8. - Effect of nest quality}

In one of the $5^{\circ} \mathrm{C}$ groups of the first series, the addition of cellulose handerkerchiefs allowed the mothers to build more compact nests than when only shavings and hay were offered. An exceptional survival rate is thus noted after weaning, i.e. $77 \mathrm{p}$. Ioo instead of $\mathrm{I} 8$ to $26 \mathrm{p}$. IOo (table I).

On the contrary, at $33^{\circ} \mathrm{C}$ the mothers do not take care of the nest built before birth.

\section{DISCUSSION}

The survival of field-vole pups during the first month of life depends in a large part on ambient temperature; the lower is the temperature, the higher is the mortality rate. The same phenomenon is observed in another vole, Microtus ochrogaster, (GIER and Cooksey, I967), rat (ChEVILIARD and CADot, I963) and mouse (BARNETT and MANL,Y, I959).

Low mortality rate during the suckling period, the abrupt death of a large number of young following weaning and the relationship individual weighttemperature-mortality indicate that two thermoregulation systems are involved.

GEBCZYNSKI (I969) notes social thermoregulation in Clethrionomys glareolus; animals in a group use less oxygen. The efficacy of this thermoregulation is related to group size and weight. The relationship observed here between litter weightfuture survival and the effect of the withdrawal of the mother from the nest account for this first method of thermoregulation in Microtus arvalis. 
However, in the field-vole individual thermoregulation appears to be more important to survival of the pups. In this species, chemical thermoregulation depending on consumption of $\mathrm{O}_{2}$ and body temperature changes under various ambient temperatures, is well-pronounced only under conditions of higher environmental temperature $\left(28^{\circ} \mathrm{C}-35^{\circ} \mathrm{C}\right)$. Thermoregulation appears on day no and is completely functional at the end of the third week (BAsHENINA, I960). The results in this study show that thermoregulation is not efficiency before at last $\mathrm{I}_{4}$ days, and certainly not before the pup has reached a minimum body weight which is higher as the temperature is lower.

At $33^{\circ} \mathrm{C}$ (the temperature at which the pups are smallest) thermoregulation does not seem imperative to survival after weaning. $33^{\circ} \mathrm{C}$ represents the thermal neutrality point in adult field-voles (RIGAUDik̀RE, Ig66).

Partial mortality of some litters may be explained by heterogeneity within the litter. In Clethrionomys rutilus the temperature of some individuals in the same litter is regulated at I3-I4 days; others are incapable of this regulation before I7 or I8 days (MORRISON et al., I954).

The role of the nest in litter thermoregulation is also very important; it has been noted that survival at $5^{\circ} \mathrm{C}$ is improved when abundant nest construction material is provided. CotTon and GRIFFITHs (I967) observed that the temperature inside the nest of Clethrionomys glareolus does not go lower than $10^{\circ} \mathrm{C}$ when the outside temperature falls from $15^{\circ} \mathrm{C}$ to $0^{\circ} \mathrm{C}$. In another field-vole, Microtus ochrogaster, the pups cannot survive without a nest at temperatures lower than Io $^{\circ} \mathrm{C}$ (GIER and CoOKSEY, I967).

As the temperature rises, the necessity for a nest decreases; at $33^{\circ} \mathrm{C}$ pups can live without a nest. In mouse, the mother even disperses the pups when the temperature rises above $32^{\circ} \mathrm{C}$ (PENNYCUIK, I964).

In this experiment females were not acclimatized to the experimental temperatures of $5^{\circ} \mathrm{C}$ and $33^{\circ} \mathrm{C}$ before parturition. Their feeding and maternal behavior may be modified during the adaptation period, i.e. during the suckling period. Food intake in field-vole (CAILLOL and MARTINET, I976) or in rat (RouBICEK et al., I968) and mouse (BARNETT and LITTLE, I965) decreases when the temperature rises. The mammary gland secretory tissue in mouse is less developed at $34^{\circ} \mathrm{C}$ than at $2 \mathrm{I}^{\circ} \mathrm{C}$ (PENNYCUIK, I966). This may explain that in vole as in rat (HEARNSHAw and WodzICKATOMASZEWSKA, I973) there is high pup mortality in the first week of lactation and the surviving pups grow slowly when it is hot.

The cold, on the other hand, does not change feeding or maternal behavior. The nest is even better built than at $2 \mathrm{I}^{\circ} \mathrm{C}$ and the pups are at least as big. However, the pups may not react as well, thus also accounting for mortality after weaning. GEBCZYNSKr (I969) observed that when it was cold the pups did not try to leave the nest and ate rarely. This is also a sign of deficient thermoregulation, at least in hibernating mammals.

The quality of vegetation eaten by the mother, then by the pups, also affects survival rate. The unfavorable role of alfalfa harvested in the fall at a late vegetative stage, has already been noted in a previous study (MARTINEr and MEUNIER, I969). The feeding value of alfalfa probably has direct influence on the mother's milk production and on the young; growth is more or less retarded and we know that weight of the young at weaning is the most important criterium for 
future survival. Ambient humidity recorded throughout the experiment was not controlled; so it is not possible to estimate its effect on pup survival and its interaction with temperatures. However it appeared that the hygroscopic properties of the nesting materials protected the interior from excessive moisture or dryness (STARK, I963). GETz (I963) did not found any significant difference in the total evaporative water losses of the meadow vole between relative humidity of $50 \mathrm{p}$. Ioo and $96 \mathrm{p}$. Ioo at $27^{\circ} \mathrm{C}$. In our study, humidity lower thant $50 \mathrm{p}$. 100 at $33^{\circ} \mathrm{C}$ may explain slow body growth as it was shown in the mice (ELLENDORF and al., I970).

Microtus arvalis, and particularly the pups, are never subjected to a $33^{\circ} \mathrm{C}$ temperature in the fields. On the other hand, $5^{\circ} \mathrm{C}$ and $2 \mathrm{I}^{\circ} \mathrm{C}$ are the mean temperatures at a depth of $20-30 \mathrm{~cm}$ in the ground from December to February and in July and August in the Poitou district (table 6). In this district survival rates in the pups: during the first month are about 6 to $25 \mathrm{p}$. Ioo from January to April and 30 to. $5^{\circ} \mathrm{p}$. Ioo from July to October (MARTINET and SPITZ, I97I).

\section{TABLE 6}

Temperature in the ground at 9 A.M.

Monthly mean from 1967 to 1973 as recorded at Lusignan in Poitou by the forage plant improvement station of the I.N.R.A.

\begin{tabular}{l|c|c}
\hline \multicolumn{1}{c|}{ Month } & $20 \mathrm{~cm}$ depth & $30 \mathrm{~cm}$ depth \\
\hline & & \\
December $\ldots \ldots \ldots \ldots \ldots$ & $5.3 \pm 0.2$ & $6.0 \pm 0.2$ \\
January $\ldots \ldots \ldots \ldots \ldots$ & $\begin{array}{l}4.7 \pm 0.2 \\
\text { February } \ldots \ldots \ldots \ldots \ldots\end{array}$ & $5.2 \pm 0.4$ \\
\hline July $\ldots \ldots \ldots \ldots \ldots \ldots$ & $20.3 \pm 0.4$ & $19.9 \pm 0.3$ \\
August $\ldots \ldots \ldots \ldots \ldots$ & $19.9 \pm 0.4$ & $19.9 \pm 0.4$ \\
\hline
\end{tabular}

The effect of cold temperature and poor food value of alfalfa in the fall on the survival of the young observed in this study may partly explain the figures obtained in nature.

Reç pour publication en mars 1976.

\section{RÉSUMÉ}

INFLUENCE DE LA TEMPÉRATURE SUR IAA SURVIE

AU COURS DU PREMTER MOIS DE LA VIE

CHEZ LE CAMPAGNOL DES CHAMPS, MICROTUS ARVALIS, ÉLEVÁ SOUS DIFFÉRENTES CONDITIONS DE PHOTOPÉRIODE ET D'ALIMENTATION

La température d'élevage joue un rôle primordial dans la survie des jeunes campagnols au cours du premier mois de la vie ; plus la température est basse et plus la mortalité augmente. L'absence d'une thermorégulation efficace au moment du sevrage explique cette mortalité 
La qualité de la luzerne consommée intervient aussi sur la survie : une luzerne récoltée au printemps à un stade végétatif précoce permet une meilleure survie des jeunes qu'une luzerne récoltée en automne à un stade végétatif plus tardif.

La durée d'éclairement quotien n'intervient pas dans la survie du campagnol de la naissance à un mois.

Les deux facteurs défavorables à la survie, température basse et luzerne d'automne, peuvent expliquer en partie les taux de mortalité observés dans la nature au cours du premier mois de la vie.

\section{REFERENCES}

Barnett S. A., Manly B. M., 1958. Adaptation to cold in young mice. Physiologia Boltemoslovenica, 8, 295-304.

Barnett S. A., Little M. J., r965. Maternal performance in mice at $-3^{\circ} \mathrm{C}$. Food consumption and fertility.' Proc. Roy. Soc., Ser. B, 162, 492-5or.

Bashenina N. V., ig6o. Ontogenèse de la thermorégulation chez le Campagnol des champs (Microtus arvalis) et chez Lagarus Lagurus. Faune et Écologie des Rongeurs, 6, I I I-r 54 (en russe).

Caillol M., Martinet L., I976. Effect of ambient temperature on food, nitrogen and energy intake of the field vole, Microtus arvalis under different conditions of daylight ratio and feeding. Ann. Biol. anim. Bioch. Biophys, 16, 783-79o.

Chevillard L., Cadot M., I963. Influence de la température extérieure sur la reproduction du Rat Long Evans. C. R. Soc. Biol, 167, $1388-1390$.

Cotton M. J., Griffiths D. A., I967. Observations on temperature conditions in vole nests $J$. Zool. London, 158, 54I-568.

Ellendorf F., Smidt D., Monzavifar M., Boer P. (de), 197o. Temperatur, luftfeuchtigkeit und Fortpflanzung bei Maũsen. II. - Einfluss von $35^{\circ} \mathrm{C}, 45$ p. 10o und 91 p. Ioo RF auf Köpergewicht und genitaltrakt. Int. J. Biometeor., 14, 85-93.

Gebczynski M., r969. Social regulation of body temperature in the bank vole. Acta Theriol., 14, 427-440.

GETz L. L., 1963. A comparison of the water balance of the prairie and meadow voles. Ecology, 44, 202-207.

GieR H. T., Cooksey B. F. Jr., I967. Microtus ochrogaster in the laboratory. Trans. Kans, Acad. 70, 256-265.

Hearnshaw H., Wodzicka-Tomaszewska M., 1973. Effect of high ambient temperature in early and late lactation on litter growth and survival in rats. Aust. J. Biol. Sci., 26, I171-1 I78.

Krebs C. J., Keller B. L., TAmarin R. H., 1969. Microtus population biology : Demograph changes in fluctuating populations of Microtus ochrogaster and Microtus pennsylvanicus in southern Indiana. Ecology, 50, 587-607.

Martinet L., Meunier M., I969. Influence des variations saisonnières de la Luzerne sur la croissance, la mortalité et l'établissement de la maturité sexuelle chez le Campagnol des Champs (Microtus arvalis). Ann. Biol. anim. Bioch. Biophys., 8, 451-462.

Martinet L., Spitz F., I97I. Variations saisonnières de la croissance et de la mortalité du Campagnol des champs, Microtus arvalis. Rôle du photopériodisme et de la végétation sur ces variations. Mammalia, 35, 38-84.

Morrison P. R., Ryser F. A., Stuker R. L., 1954. Growth and development of temperature regulation in the tundra Redback Vole. J. Mammal., 35, 376-386.

Pennycuik P. R., I 964 . The effects on rats of chronic exposure to $34^{\circ} \mathrm{C}$. I. The effect of variations in the diet on growth and on the ability of mothers to rear pups to weaning age. Aust. J. Biol. Sci., 17, 208-219.

Pennycuik P. R., r966. Differences between mice gestating and lactating at $21^{\circ}$ and at $34-3^{\circ}$ with particular reference to the mammary gland. Austr. J. Exp. Biol. Med. Sci., 44, 419-438.

Rigaudière N., I966. Étude des modifications du point de neutralité thermique et du métabolisme de base chez le Campagnol soumis à des variations de la température d'élevage. C. $R$. Soc. Biol., 160, I577-I $58 \mathrm{I}$.

Roubicek C. B., Ray D. E., Tucka H., I968. Performance of rats at constant and intermittent temperatures and with four feeding schedules. Growth, 32, I35-I4I.

Spitz F., I974. Démographie du Campagnol des champs, Microtus arvalis, en Vendée. Ann. Zool. Écol. Anim., 6, 259-312.

STARK H., 1963. Nesting habits of the Californian vole, Microtus californicus and microclimatic factors affecting the nest. Ecology, 44, 663-669. 